Disclosures

\begin{tabular}{|c|c|c|c|c|c|c|c|}
\hline $\begin{array}{l}\text { Writting group } \\
\text { member }\end{array}$ & Employment & $\begin{array}{l}\text { Research } \\
\text { grant }^{1}\end{array}$ & $\begin{array}{c}\text { Other research grant } \\
\text { or medical continuous } \\
\text { education }^{2}\end{array}$ & $\begin{array}{l}\text { Speaker's } \\
\text { honoraria }\end{array}$ & $\begin{array}{c}\text { Ownership } \\
\text { interest }\end{array}$ & $\begin{array}{l}\text { Consultant/ } \\
\text { Advisory } \\
\text { board }\end{array}$ & Other ${ }^{3}$ \\
\hline $\begin{array}{l}\text { Giovanni } \\
\text { Abrahão Salum }\end{array}$ & HCPA/UFRGS & $\begin{array}{c}\text { CNPq } \\
\text { FIPE/HCPA }\end{array}$ & - & - & - & - & - \\
\hline Carolina Blaya & HCPA/UFRGS & $\begin{array}{c}\text { CAPES } \\
\text { FIPE/HCPA }\end{array}$ & - & Eli-Lilly* & - & - & - \\
\hline $\begin{array}{l}\text { Gisele Gus } \\
\text { Manfro }\end{array}$ & HCPA/UFRGS & $\begin{array}{c}\text { CNPq } \\
\text { FIPE/HCPA }\end{array}$ & - & $\begin{array}{c}\text { Eli-Lilly* } \\
\text { Boehringer* }\end{array}$ & - & - & Roche* \\
\hline Jair Segal & HCPA/UFRGS & $\begin{array}{c}\text { CNPq } \\
\text { FIPE/HCPA }\end{array}$ & - & - & - & - & - \\
\hline $\begin{array}{l}\text { Sandra Leistner- } \\
\text { Segal }\end{array}$ & HCPA/UFRGS & $\begin{array}{c}\text { CNPq } \\
\text { FIPE/HCPA }\end{array}$ & - & - & - & - & - \\
\hline
\end{tabular}

* Modest

** Significant

*** Significant. Amounts given to the author's institution or to a colleague for research in which the author has participation, not directly to the author. Note: HCPA = Hospital de Clínicas de Porto Alegre; FIPE/HCPA = Fundo de Incentivo à Pesquisa do Hospital de Clínicas de Porto Alegre; UFRGS = Universidade Federal do Rio Grande do Sul; CNPq = Conselho Nacional de Desenvolvimento Científico e Tecnológico; CAPES = Coordenação de Aperfeiçoamento de Pessoal de Nível Superior.

For more information, see Instructions for authors.

References

1. Cordeiro Q, Souza BR, Correa H, Guindalini C, Hutz MH, Vallada H, RomanoSilva MA. A review of psychiatric genetics research in the Brazilian population. Rev Bras Psiquiatr. 2009;31(2):154-62.

2. Blaya C, Moorjani P, Salum GA, Goncalves L, Weiss LA, Leistner-Segal S, Manfro GG, Smoller JW. Preliminary evidence of association between EFHC2, a gene implicated in fear recognition, and harm avoidance. Neurosci Lett. 2009;452(1):84-6.

3. Wachleski C, Blaya C, Salum GA, Vargas V, Leistner-Segal S, Manfro GG. Lack of association between the serotonin transporter promoter polymorphism
(5-HTTLPR) and personality traits in asymptomatic patients with panic disorder. Neurosci Lett. 2008;431(2):173-8.

4. Segal J, Schenkel LC, Oliveira MH, Salum GA, Bau CH, Manfro GG, LeistnerSegal S. Novel allelic variants in the human serotonin transporter gene linked polymorphism (5-HTTLPR) among depressed patients with suicide attempt. Neurosci Lett. 2009;451(1):79-82.

5. Segal J, Pujol C, Birck A, Gus Manfro G, Leistner-Segal S. Association between suicide attempts in south Brazilian depressed patients with the serotonin transporter polymorphism. Psychiatry Res. 2006;143(2-3):289-91.

\section{Population stratification in European South-American subjects and its importance to psychiatric genetics research in Brazil}

\section{Estratificação populacional em sul-americanos de origem européia e sua importância para a pesquisa genética psiquiátrica no Brasil}

\section{Dear Editors,}

It is really very exciting to know that another Brazilian group is working with molecular investigation in the field of psychiatric genetics. ${ }^{1}$ When we decided to write a paper about the particularities, advantages and difficulties of conducting psychiatric genetic studies in the Brazilian population, we were aware of the possible biases of a narrative review. ${ }^{2}$ However, that kind of approach seemed to be a more appropriate method in terms of our proposal because we believe that, by describing the history, development, and management of psychiatric genetic investigations in Brazil, we would be contemplating several contextual, cultural and political aspects and integrating different and independent fields of research in order to acquire a wider and multidisciplinary view of the subject at hand.

There is also another important point raised by Salum et al. ${ }^{1}$ that needs to be addressed. Differently from what they claim, the use of "more homogenous samples like the Caucasians" does not "avoid stratification" in association studies on complex disorders such as neuropsychiatric disorders. ${ }^{2}$

Nowadays, it is well known that even when studying samples from a specific continental population such as the European, ethnic stratification can produce false associations at markers whose frequency differs across subpopulations. ${ }^{3}$ For example, in a recent whole genome association study of rheumatoid arthritis in European Americans, markers in the LCT and IRF4 genes could have been falsely implicated as being associated with the disease had no control method been applied to for the population's 
stratification. ${ }^{4}$ Certain studies have suggested that angiotensin I converting enzyme (ACE) gene polymorphism is associated with an increased risk of late onset Alzheimer's disease. However, when studying this, Panza et al. have found inconsistent findings within European studies. ${ }^{5}$ Interestingly, there is a statistically significant decreasing trend of the $A C E^{*} I /{ }^{*} \mathrm{D}$ genotype frequency from northern to southern regions of Europe, which may contribute to explain the different patterns of associations found between such polymorphism and Alzheimer's disease across Europe. ${ }^{5}$ Recent investigations have suggested that genetic association studies in European Americans should use ancestry informative markers for examining north-south, Ashkenazi Jewish, and Irish ancestry. ${ }^{3}$

Several statistical methods have been developed to control for population stratification. Some studies have proposed that, considering that a small number of candidate markers may not be sufficiently informative and that genotyping a large number of markers can be expensive, the use of microarrays for ancestry estimation and correction has to be considered as a valuable tool when attempting to identify genes for complex traits through association studies involving European and European American populations. However, while studying subjects from European ancestry in Rio Grande do Sul, which is also Mr. Salum and his colleagues' home state, a group of Brazilian researchers found a hidden ethnic admixture and proposed an interesting and cheap genomic control that can be used at the individual level, thus correcting for stratification by removing certain individuals from the sample without losing any statistical power due to statistical corrections. ${ }^{6}$

Quirino Cordeiro, Homero Vallada

Program of Genetics and Pharmacogenetics, Department and Institute of Psychiatry, Universidade de São Paulo (USP) Medical School, São Paulo (SP), Brazil

\section{Bruno Rezende Souza, Humberto Correa,} Marco Aurélio Romano-Silva

Department of Mental Health, Medical School, Universidade Federal de Minas Gerais (UFMG), Belo Horizonte (MG), Brazil

\section{Camila Guindalini}

Interdisciplinary Laboratory of Clinical Neuroscience, Department of Psychiatry, Universidade Federal de São Paulo (UNIFESP), São Paulo (SP), Brazil

Mara Helena Hutz

Department of Genetics, Universidade Federal do Rio Grande do Sul (UFRGS), Porto Alegre (RS), Brazil

\section{Disclosures}

\begin{tabular}{|c|c|c|c|c|c|c|c|}
\hline $\begin{array}{l}\text { Writting group } \\
\text { member }\end{array}$ & Employment & $\begin{array}{l}\text { Research } \\
\text { grant }^{1}\end{array}$ & $\begin{array}{c}\text { Other research grant } \\
\text { or medical continuous } \\
\text { education }\end{array}$ & $\begin{array}{l}\text { Speaker's } \\
\text { honoraria }\end{array}$ & $\begin{array}{c}\text { Ownership } \\
\text { interest }\end{array}$ & $\begin{array}{c}\text { Consultant/ } \\
\text { Advisory } \\
\text { board }\end{array}$ & Other ${ }^{3}$ \\
\hline \multirow[t]{2}{*}{ Quirino Cordeiro } & $\begin{array}{l}\text { Hospital João } \\
\text { Evangelista }\end{array}$ & - & - & - & - & - & - \\
\hline & $\begin{array}{c}\text { Associação } \\
\text { Congregação de } \\
\text { Santa Catarina }\end{array}$ & & & & & & \\
\hline Homero Vallada & USP & - & - & - & - & - & - \\
\hline $\begin{array}{l}\text { Bruno Rezende } \\
\text { Souza }\end{array}$ & UFMG & - & - & - & - & - & - \\
\hline $\begin{array}{l}\text { Humberto } \\
\text { Correa }\end{array}$ & UFMG & - & - & - & - & - & - \\
\hline $\begin{array}{l}\text { Marco Aurélio } \\
\text { Romano-Silva }\end{array}$ & UFMG & $\begin{array}{c}\text { CNPq } \\
\text { FAPEMIG } \\
\text { INCT de } \\
\text { Medicina } \\
\text { Molecular*** }\end{array}$ & - & - & - & - & - \\
\hline $\begin{array}{l}\text { Camila } \\
\text { Guindalini }\end{array}$ & UNIFESP & & - & Eli-Lilly* & - & - & - \\
\hline $\begin{array}{l}\text { Mara Helena } \\
\text { Hutz }\end{array}$ & UFRGS & $\begin{array}{l}\text { CNPq }^{* * *} \\
\text { PRONEX } \\
\text { Institutos do } \\
\text { Milênio }\end{array}$ & - & - & - & - & - \\
\hline
\end{tabular}

* Modest

** Significant

*** Significant. Amounts given to the author's institution or to a colleague for research in which the author has participation, not directly to the author. Note: USP = Universidade de São Paulo; UFMG = Universidade federal de Minas Gerais; UNIFESP = Universidade Federal de São Paulo; UFRGS = Universidade Federal do Rio Grande do Sul; CNPq = Conselho Nacional de Desenvolvimento Científico e Tecnológico; FAPEMIG = Fundação de Amparo à Pesquisa do Estado de Minas Gerais; PRONEX = Programa de Apoio a Núcleos de Excelência.

For more information, see Instructions for authors. 
References

1. Salum GA, Blaya C, Segal J, Manfro GG, Leistner-Segal S. Emerging research groups in Brazilian psychiatric genetic studies. Rev Bras Psiquiatr. In press 2009.

2. Cordeiro Q, Souza BR, Correa H, Guindalini C, Hutz MH, Vallada H, RomanoSilva MA. A review of psychiatric genetics research in the Brazilian population. Rev Bras Psiquiatr. 2009;31(2):154-62.

3. Seldin MF, Price AL. Application of ancestry informative markers to association studies in European Americans. PLoS Genet. 2008;4(1):e5

4. Tian C, Plenge RM, Ransom M, Lee A, Villoslada P, Selmi C, Klareskog L, Pulver AE, Gregersen PK, Seldin MF. Analysis and application of European genetic substructure using $300 \mathrm{~K}$ SNP information. PLoS Genet. 2008;4(1):e4.

5. Panza F, Solfrizzi V, D’Introno A, Colacicco AM, Capurso C, Capurso A, Kehoe PG. Shifts in angotensin I converting enzyme insertion allele frequency across Europe: implications for Alzheimer's disease risk. $J$ Neurol Neurosurg Phychiatry. 2003;74(8):1159-61.

6. Zembrzuski VM, Callegari-Jacques SM, Hutz MH. Application of an African Ancestry Index as a genomic control approach in a Brazilian population. Ann Hum Genet. 2006;70(6):822-8.

\section{Treatment of apathy in Alzheimer's disease with transdermal rivastigmine: report of three cases}

\section{Tratamento da apatia na doença de Alzheimer com rivastigmina transdérmica: relato de três casos}

\section{Dear Editor,}

Apathy in Alzheimer's disease is one of the most difficult behavioral and psychological symptoms to treat. Anticholinesterasic drugs, dopaminergic agonists, and psychostimulants are treatment alternatives based on studies with contradictory results. ${ }^{1}$ The use of transdermal rivastigmine has not been sufficiently studied in clinical trials, especially regarding the treatment of apathy. We report below 3 cases of dementia and apathy treated with transdermal rivastigmine, with behavioral symptoms analysis, cognitive testing and outcome measurement in the first, second, third and sixth months.

Case reports: Three female patients were evaluated - MO (81 years old), ECN (74 years old) and DM (84 years old) - all of them meeting the criteria for Alzheimer's Disease (based on DSMIV) and for apathy (based on the following criteria proposed by Robert P, 2009: ${ }^{2}$ 1) the core feature of apathy, diminished motivation, must be present for at least four weeks; 2) two of the three dimensions of apathy (reduced goal-directed behaviour, goaldirected cognitive activity, and emotions) must also be present; 3) there should be identifiable functional impairments attributable to apathy; 4) exclusion criteria are specified to exclude symptoms and states that mimic apathy. After the diagnosis of Alzheimer's disease, the patients were treated with transdermal rivastigmine (4.6mg in the first month and $9.5 \mathrm{mg}$ after the second month). The improvement of apathy was observed after the introductions of anticholinesterasic treatment. The three cases are presented below:

1) DM presented at first meeting with: Mini Mental State Examination (MMSE) of $15 / 30$, poor verbal contact, walking impairment, loss of manual abilities, and social isolation. After two months of treatment, the patient started to interact during the examination, returned to her manual and social activities, improved her walking balance and presented a MMSE of 21/30. After six months, the improvements were maintained.

2) ECN presented at first meeting with: MMSE of 20/30, difficulties in verbal contact, loss of instrumental activities of daily living (iADL), and social isolation. After two months of treatment, the patient returned with great improvement in verbal contact, returned to her $\mathrm{iADL}$ and presented a MMSE of 22/30. After six months, the improvements were maintained.

3) MO presented at first meeting with: MMSE of 13/30, poor verbal contact, loss of iADL and interruption of her morning exercise (walking). After two months of treatment, the patient was more collaborative, showed iADL improvement, returned to her physical activity and presented an MMSE of 10/30. The improvements were maintained after 6 months.

Discussion: Apathy is the most common neuropsychiatric syndrome in Alzheimer's disease, affecting 30 to $60 \%$ of patients. ${ }^{1,2}$ Its pharmacologic therapy is based on three strategies: psychostimulants, dopaminergic agonists and anticholinesterasic drugs. ${ }^{1}$

Despite being first tested and developed for the improvement of cognition in Alzheimer's disease, anticholinesterasic drugs showed many benefits in the treatment of behavioral and psychological symptoms related to dementia, including apathy. Although systematic reviews point to a lack of well-designed studies concerning this issue, anticholinesterasic drugs remain as an appropriate therapy for apathy. ${ }^{3,4}$ The new presentation of transdermal rivastigmine has been studied as an option with fewer adverse effects (nausea and vomiting) when compared to other oral anticholinesterasic drugs, ${ }^{5}$ but no studies concerning their use in behavioral symptoms have been conducted. In the cases reported above, there was a surprising improvement in the apathy of all patients, regardless of the changes in cognitive function. This finding brings new perspectives for the conduction of future randomized and double-blind studies evaluating the use of transdermal rivastigmine.

Alessandra Lamas Granero, Giancarlo Lucchetti Interdisciplinary Center for Assistance and Research on Aging, Medical Sciences School of Minas Gerais, Belo Horizonte (MG), Brazil Geriatric Clinic - São Paulo Commerce Workers Union, Brazil 